International Journal of Engineering \&Technology, 8(4) (2019) 473-477
International Journal of Engineering \& Technology
SPC
Website: www.sciencepubco.com/index.php/IJET
Research paper

\title{
Controllable and flexible energy production in a water-based photovoltaic/thermal system
}

\author{
AA. Aminou Moussavou ${ }^{1}$, AK. Raji ${ }^{1}$, M. Adonis ${ }^{1}$ \\ ${ }^{1}$ CDES, Dept. of Electrical, Electronic and Computer Engineering, Cape Peninsula University of Technology, South Africa \\ *Corresponding author E-mail: akdech80@yahoo.fr
}

\begin{abstract}
A combined solar photovoltaic and thermal (PV/T) system is not just a product that makes our life easier, nor is it a luxury. In the future economics will make the use of the PV/T system essential. The purpose of this to improve the energy balance in a PV/T system, by controlling the thermal energy (useful heat) production for the domestic hot water as well as the electrical production. Simulation and analysis of a simplified model of the PV/T system for cooling the PV cell and heating the working fluid inside of the absorber pipe attached at the back of the PV cell were implemented in MATLAB /Simulink software. The optimal electrical and thermal power were obtained by selecting a par-ticular value of Rse that partially converts the output of the PV cell into useful thermal energy. It was discovered that increasing the chosen value of Rse results in higher heat dissipation in the PV/T cell, an increase in thermal efficiency, and also a decrease in electrical efficiency.
\end{abstract}

Keywords: Efficiency; Photovoltaic Systems; Modelling and Simulation; Power Production; PV/T Collector; Thermal Energy; Electrical Energy.

\section{Introduction}

Solar modules convert only 4 to $17 \%$ of solar radiation, depending on the type of solar cell and the operating conditions [1]. Most of the solar energy captured by photovoltaic is converted to wasted heat, causing the degradation of the module and reduction in energy efficiency. Cooling the solar module using air or water can significantly increase the energy yield by reducing its temperature. PV/T collector is a combination of photovoltaic and solar thermal (PV/T) components that generate simultaneously electrical and thermal energy [2]. This double function of PV/T allows using of the solar energy more efficiently and result in higher solar energy conversion, depending on the fluid used and the shape of the pipe, such as PV/T air and PV/T water [3].

Simple solar PV and thermal technology is an effective alternative to increase initial energy savings by consuming less energy.

The introduction of modern technological applications for heating and cooling have become novel. Therefore, the majority of the heating systems need to be equipped with conventional water heaters that make use of fossil fuels or electricity for heat production [5]. As a consequence, these systems provide an inefficient energy conversion that negatively affects the environment. However, sustainable energies such as renewable energy have demonstrated promising developments as they take into account the growing ecological constraints [5], [6]. Of all renewable energies, solar energy is considered the most sustainable energy source used, especially photovoltaic and solar thermal technology [4].

In the literature of solar energy and cooling such as the development of a widely used water-based PV/T cooling over the air-cooling system. For such a module, water flows below through a pipe under the PV cell layer, and this improves the PV cell productivity through the chill. Likewise, the running water temperature would rise as taking away the generated heat from PV cells. The heated water can go about as a decent warmth hotspot for warm household applications, and sun oriented helped warming and cooling innovations. The hot water can act as an excellent heat source for residential and architectural applications and solar-assisted heating and cooling technologies [7], [8].

Therefore, in this present study, the focus is to determine the energy impact created due to the combination of photovoltaic and thermal energy (PV/T). These systems provide analysis and modelling of the energy utilisation of PV/T system, as well as the balance of exchange of heat and electrical power generated. Also, the interaction between these systems would increase the energy efficiency of both photovoltaic and thermal energy.

\section{Proposed PV/T model}

In this present study, it is proposed to improve the efficiency of a simple water PV/T system. The purpose of the proposed model is to analyse the cooling method and the possibility of partially converting photovoltaic electrical into useful heat source (thermal absorber). The working fluid plays the role of cooling the PV cells and therefore boosting the PV cell performance. A control method can adjust the useful heat transfer capacity to working fluid based on energy demand. 


\subsection{A mathematical model of the thermal performance of the PV/T system}

The solar radiation is assumed to be perpendicular to the surface of the PV/T module. Different equations allow for evaluation of the energy extracted, the temperatures of the elements and fluid at the inlet and outlet, as well as PV/T system yields. The mathematical equations of the design provided in this study, do not need to be optimally determined. Fig. 1 shows the characteristics of heat transfer of the PV/T system.

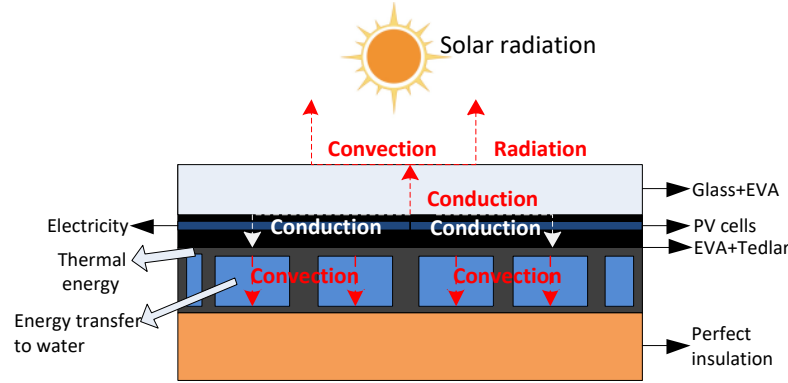

Fig. 1: Heat Transfer Characteristics of the PV/T System.

- Energy balance in the absorber pipe

The energy of the fluid in the absorber pipe can be changed by an assortment of procedures. These include advection and conduction through the terminals of the pipe (thermal liquid ports A and B), convection at the pipe-fluid interface (thermal port $\mathrm{H}$ ). The energy balance regarding the energy accumulation rate in the pipe is expressed as follows:

- Convective heat transfer at the pipe wall

The heat flow rate between the thermal liquid and the pipe wall is assumed to result from a convective exchange and a purely conductive exchange:

$\phi_{H}=Q_{\text {conv }}+Q_{\text {cond }}$

The heat flow rate due to conduction is computed as follows:

$Q_{\text {cond }}=\frac{k i \cdot S_{H}}{D}\left(T_{H}-T_{I}\right)$

Where:

$\mathrm{k}_{\mathrm{i}}$ represents the thermal conductivity of the liquid inside the pipe; and

$\mathrm{S}_{\mathrm{H}}$ represents the surface area of the pipe wall (the product of the internal perimeter and the pipe length).

$\mathrm{T}_{\mathrm{H}}$ represents the temperature of the pipe wall

$\mathrm{T}_{\mathrm{i}}$ represents the temperature inside the pipe wall

The subscripts $\mathrm{H}$ and I denote the pipe wall and the internal fluid volume, respectively.

The heat flow rate due to convection is computed as follows:

$Q_{c o n v}=c_{p, a v g}\left|\dot{m}_{\text {avg }}\right|\left(T_{H}-T_{i n}\right)\left[1-\exp \left(\frac{h \cdot S_{H}}{c_{p, a v g}\left|\dot{m}_{\text {avg }}\right|}\right)\right]$

Where:

$c_{p, a v g}$ denotes the specific heat of the thermal liquid at the average temperature of the pipe;

$\mathrm{h}$ denotes the heat transfer coefficient of the pipe;

$\dot{m}_{\text {Avg }}$ denotes a mass flow rate at the average temperature into the pipe;

$T_{i n}$ denotes temperature inlet of the pipe;

\subsection{Technical parameters of the PV/T system}

The technical parameters of the PV/T system and heat exchangers are shown in

Table 1. In a closed loop system, the circulation pump must overcome the head pressure each time the machine is turned on. Besides, the pump must be compatible with the hydraulic characteristics of the PV/T system. The initial design parameters $\mathrm{C}_{\mathrm{W}}=4190 \mathrm{~J} / \mathrm{kgK}$; ambient temperature $20^{\circ} \mathrm{C}$; Time of simulation 3 hours.

Table 1: PV/T System Parameters Detail

\begin{tabular}{lll}
\hline Component & Parameter & Value \\
\hline PV modules & Cell type & mono-crystalline \\
& Packing factor & 0.91 \\
& Conversion efficiency & $16 \%$ \\
& Module peak power & $3.25 \mathrm{~kW}$ \\
& Maximum voltage, $\mathrm{V}_{\mathrm{m}}$ & $255 \mathrm{~V}$ \\
& Maximum current, $\mathrm{I}_{\mathrm{m}}$ & $12.4 \mathrm{~A}$ \\
& Open circuit voltage, $\mathrm{V}_{\mathrm{oc}}$ & $310 \mathrm{~V}$ \\
& Short circuit current, $\mathrm{I}_{\mathrm{sc}}$ & $14.64 \mathrm{~A}$ \\
\hline
\end{tabular}




\begin{tabular}{lll}
\hline & Internal Series resistance $\mathrm{R}_{\mathrm{si}} /$ cell & $0.0042 \Omega$ \\
& Parallel resistance $\mathrm{R}_{\mathrm{pi}} /$ cell & 10.1 \\
& Active total area & $12 \mathrm{~m}^{2}$ \\
Absorbed pipe & The internal diameters of tubes & $\mathrm{D}_{\mathrm{i}}=0.0027 \mathrm{~m}$ \\
& The external diameters of tubes & $\mathrm{D}_{\mathrm{o}}=0.0043 \mathrm{~m}$ \\
& Pipe total length & $\mathrm{L}=5 \mathrm{~m}$ \\
& Height & $\mathrm{L}=10 \mathrm{~m}$ \\
& Nusselt number for laminar flow & 3.66 \\
& heat transfer: & $20^{\circ} \mathrm{C}$ \\
Initial liquid temperature: & Gnielinski correlation \\
Hirculating Pump & Heat transfer parameterisation: & Fixed-discretisation pump \\
Hot water storage & Typel: & $200 \mathrm{~L}$ \\
& Capacity & $20^{\circ} \mathrm{C}$ \\
\end{tabular}

\section{Simulation results and discussion}

\subsection{Influence of external series resistance on PV performance}

This section explores the impact of external series resistance on PV cell performance. A set of values defining external series resistance $\left(R_{s e}\right)$ values is added to the internal series resistance of the PV cell, as shown in Fig. 2. The performance of the PV cell was evaluated is by calibration the value of $\mathrm{R}_{\mathrm{se}}$, to dissipate power in the form of the heat, thus creating useful heat energy.

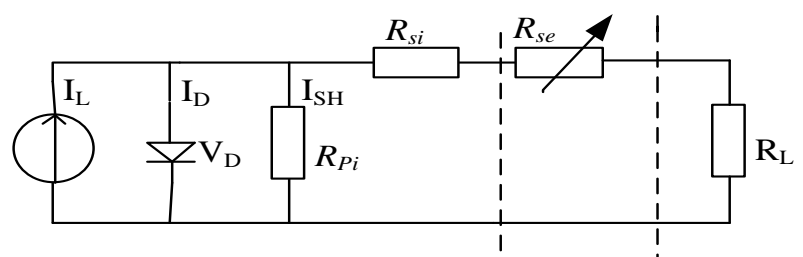

Fig. 2: Evaluation of PV Performance Under External Series Resistance.

\subsection{Prediction of PV cell temperature as a function of Rse}

Fig. 3 shows a logarithmic growth of cell temperature as a function of $R_{s e}$. Increasing in $R_{\text {se }}$ from 0 to $50 \Omega, T_{c}$ increase from 45 to $59^{\circ} \mathrm{C}$, or about $14^{\circ} \mathrm{C}$. While increasing $\mathrm{R}_{\mathrm{se}}$ from 50 to $100 \Omega$ however, only increases $\mathrm{T}_{\mathrm{c}}$ from 59 to $62^{\circ} \mathrm{C}$ or about $3^{\circ} \mathrm{C}$. The increase in the temperature is a result of a build-up of power dissipated in the form of heatError! Reference source not found.

Error! Reference source not found.To analyse and predict the PV cell temperature as a function of $\mathrm{R}_{\mathrm{se}}$, from the graph in Fig. 3, an equation was derived, relating $\mathrm{T}_{\mathrm{c}}$ to $\mathrm{R}_{\mathrm{se}}$; Equation 4 is approximatively extracted from Fig. 3.

$\mathrm{T}_{\mathrm{c}}\left(\mathrm{R}_{\mathrm{se}}\right)=\mathrm{p} 16 \cdot \mathrm{R}_{\mathrm{se}}^{4}+\mathrm{p} 17 \cdot \mathrm{R}_{\mathrm{se}}^{3}+\mathrm{p} 18 \cdot \mathrm{R}_{\mathrm{se}}^{2}+\mathrm{p} 19 \cdot \mathrm{R}_{\mathrm{se}}+\mathrm{p} 20$

Where:

p16, p17, p18, p19 and p20 are coefficients

$\mathrm{T}_{\mathrm{c}}$ is the cell temperature

Table 2 displays a polynomial interpretation of the PV cell temperature as a function of $\mathrm{R}_{\mathrm{se}}$, from the graph in Fig. 3; the coefficient of determination $\left(\mathrm{R}^{2}\right)$ is an indicator of the goodness of linear regression and it is determined to be 0.9996 .

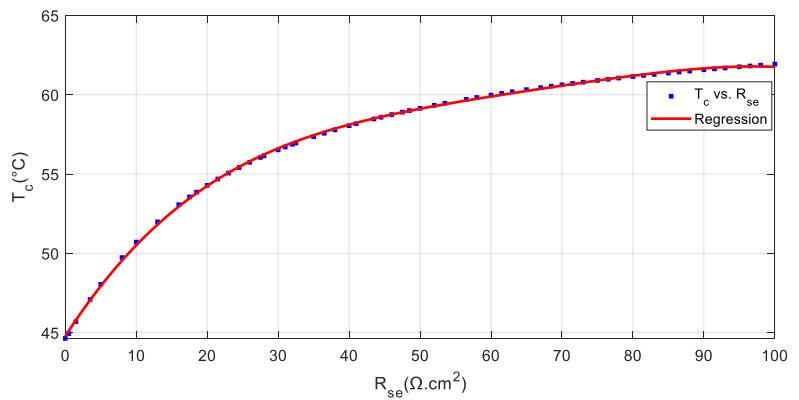

Fig. 3: PV Cell Temperature Versus $R_{\text {se }}$

Table 2: Linear Model Poly4 of Fig. 3

\begin{tabular}{ll}
\hline Description of equation & Goodness of fit \\
\hline $\mathrm{T}_{\mathrm{c}}\left(\mathrm{R}_{\mathrm{se}}\right)=\mathrm{p} 16 \cdot \mathrm{R}_{\mathrm{se}}^{4}+\mathrm{p} 17 \cdot \mathrm{R}_{\mathrm{se}}^{3}+\mathrm{p} 18 \cdot \mathrm{R}_{\mathrm{se}}^{2}+\mathrm{p} 19 \cdot \mathrm{R}_{\mathrm{se}}+\mathrm{p} 20$ & Table 2: Linear Model Poly4 of Fig. 3 \\
Coefficients (with 95\% confidence bounds): & SSE :0.4584 \\
$\mathrm{p} 1=-4.948 \mathrm{e}-07(-5.393 \mathrm{e}-07,-4.504 \mathrm{e}-07)$ & $\mathrm{R}-\mathrm{square}: 0.9996$ \\
$\mathrm{p} 2=0.0001327(0.0001239,0.0001416)$ & Adjusted $\mathrm{R}-\mathrm{square}: 0.9996$ \\
$\mathrm{p} 3=-0.01359(-0.01417,-0.01301)$ & RMSE :0.08968 \\
$\mathrm{p} 4=0.6962(0.6828,0.7096)$ & \\
$\mathrm{p} 5=44.78(44.68,44.87)$ & \\
\hline
\end{tabular}




\subsection{The temperature of the PV/T system under working fluid and Rse}

Combining the PV cell with the absorber pipe to form the PV/T. It was determined in Fig. 4 that the average $\mathrm{T}_{\mathrm{c}}$ for the PV/T system was $29.75,30.25$ and $35.75^{\circ} \mathrm{C}$ when $R_{s e}$ was set to 0,10 and $50 \Omega$, respectively. While in Fig. 3 , the average $T_{c}$ of the PV cell was 45,51 and $59{ }^{\circ} \mathrm{C}$ for the corresponding value of $\mathrm{R}_{\mathrm{se}}$. The $\mathrm{PV} / \mathrm{T}$ system temperature is substantially lower than the corresponding temperature for the $\mathrm{PV}$ cell because the water delays the rise of $\mathrm{T}_{\mathrm{c}}$ by absorbing the extra thermal energy of the system.

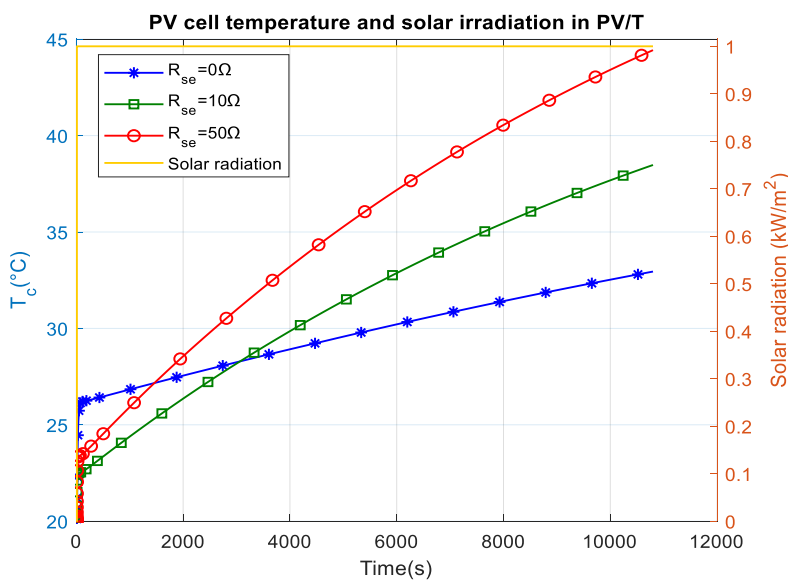

Fig. 4: PV Cell Temperature and Solar Irradiation in the PV/T System.

\subsection{Energy efficient in PV/T system under working water and selected values of Rse}

The thermal efficiency rises to 20,33 and $44 \%$, when $\mathrm{R}_{\text {se }}$ was 0,10 and $50 \Omega$, respectively, due to the startling effect. As the value of $\left(\mathrm{T}_{\mathrm{w}}\right.$ - $\left.\mathrm{T}_{\mathrm{a}}\right) / \mathrm{G}$ increases, the thermal efficiency decreases linearly from 20 to $14 \%, 33$ to $15 \%$ and 44 to $19 \%$, when Rse was 0,10 and $50 \Omega$. It was discovered that increasing the chosen value of $R_{\text {se }}$ results in higher heat dissipation in the PV/T cell, an increase in thermal efficiency, and also a decrease in electrical efficiency. As a result, the thermal efficiency of the module and the temperature of the PV cell increase, and the electrical efficiency of the PV cell reduces.

PV/T electrical system efficiency is presented in Fig. 6, the average PV/T electrical system efficiency was determined to be $15.7,8.15$ and $1.7 \%$ when $\mathrm{R}_{\mathrm{se}}$ was $0,10,50 \Omega$, respectively. While the average PV cell electrical efficiency was $14.2,7.1$ and $1.5 \%$ for the corresponding value of $\mathrm{R}_{\text {se. }}$. Therefore, the PV/T system improved the efficiency of solar energy conversion.

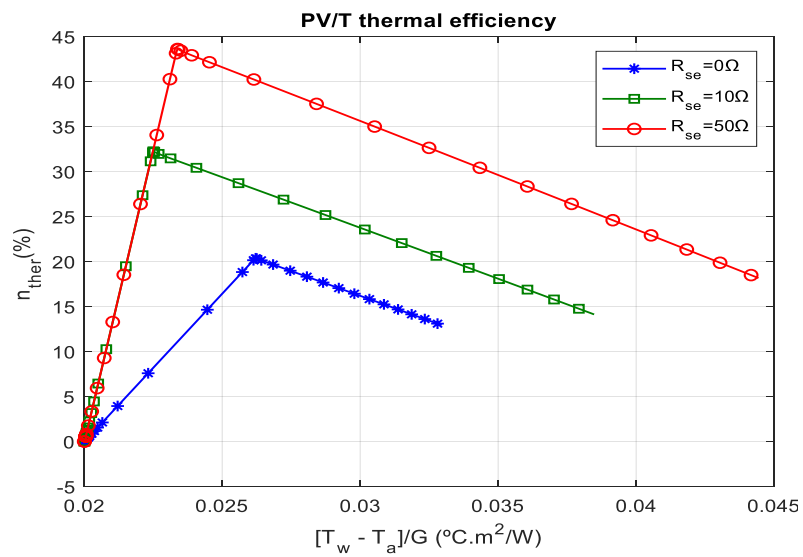

Fig. 5: PV/T System Efficiency Versus $\left[T_{w}-T_{a}\right] / G\left({ }^{\circ} \cdot M^{2} / W\right)$. 


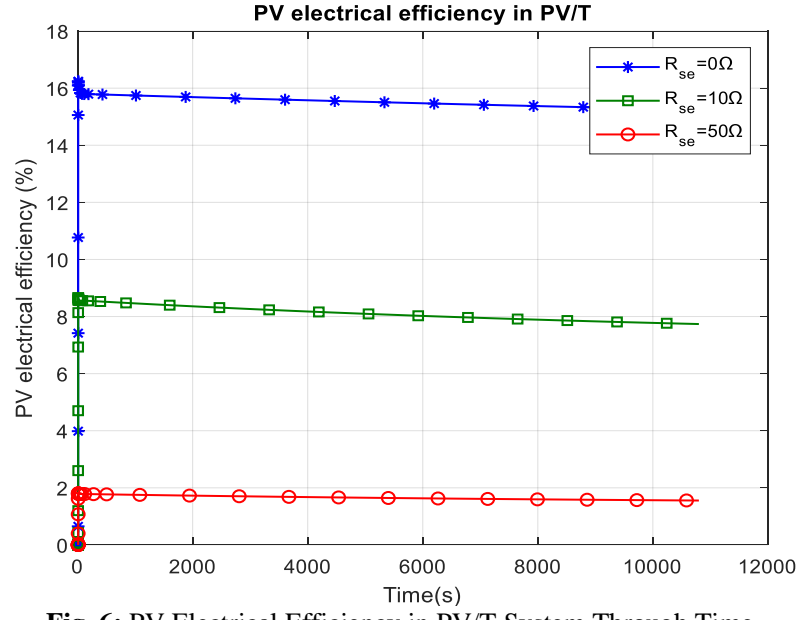

Fig. 6: PV Electrical Efficiency in PV/T System Through Time.

\section{Conclusion}

The work that has been undertaken in this paper is considered a modest contribution to understanding the complex phenomena governing heat transfer in PV/T models. The simulation results provide the temperature profiles of the PV/T model. The simulation also was indicated the cooling and heating capacity of a PV/T system. A particular value of $\mathrm{R}_{\text {se }}$ dictates the amounts of electrical power and useful thermal energy from the PV/T system. Also, to transfer thermal energy (power dissipated in the form of heat) to the working fluid inside the absorber pipe. It was discovered that increasing the chosen value of $\mathrm{R}_{\mathrm{se}}$ results in higher heat dissipation in the PV/T cell, an increase in thermal efficiency, and also a decrease in electrical efficiency. This information demonstrates the general useful energy (dissipating power in the form of heat) capacity of a PV cell to transfer heat the working fluid of the PV/T system. These results were quite encouraging for electrical power generation and domestic applications in water heating.

\section{References}

[1] A. Bai et al., "Technical and economic effects of cooling of monocrystalline photovoltaic modules under Hungarian conditions," Renew. Sustain. Energy Rev., vol. 60, pp. 1086-1099, Jul. 2016.

[2] A. Ramos, M. A. Chatzopoulou, I. Guarracino, J. Freeman, and C. N. Markides, "Hybrid photovoltaic-thermal solar systems for combined heating, cooling and power provision in the urban environment," Energy Convers. Manag., vol. 150, pp. 838-850, Oct. 2017. https://doi.org/10.1016/j.enconman.2017.03.024.

[3] H. A. Zondag, D. W. de Vries, W. G. J. van Helden, R. J. C. van Zolingen, and A. A. van Steenhoven, "The yield of different combined PV-thermal collector designs," Sol. Energy, vol. 74, no. 3, pp. 253-269, Mar. 2003. https://doi.org/10.1016/S0038-092X(03)00121-X.

[4] P. A. Owusu and S. Asumadu-Sarkodie, "A review of renewable energy sources, sustainability issues and climate change mitigation," Cogent Eng., vol. 3, no. 1, p. 1167990 , Dec. 2016.

[5] A. Chel and G. Kaushik, "Renewable energy technologies for sustainable development of energy efficient building," Alex. Eng. J., vol. 57, no. 2, pp. 655-669, Jun. 2018.

[6] D. Banks and J. Schäffler, "The potential contribution of renewable energy in South Africa," 2006.

[7] Z. A. Haidar, J. Orfi, and Z. Kaneesamkandi, "Experimental investigation of evaporative cooling for enhancing photovoltaic panels efficiency," Results Phys., vol. 11, pp. 690-697, Dec. 2018. https://doi.org/10.1016/j.rinp.2018.10.016.

[8] J. Siecker, K. Kusakana, and B. P. Numbi, “A review of solar photovoltaic systems cooling technologies,” Renew. Sustain. Energy Rev., vol. 79, pp. 192-203, Nov. 2017.

[9] H. M. Yin, D. J. Yang, G. Kelly, and J. Garant, "Design and performance of a novel building integrated PV/thermal system for energy efficiency of buildings," Sol. Energy, vol. 87, no. Supplement C, pp. 184-195, Jan. 2013. https://doi.org/10.1016/j.solener.2012.10.022.

[10] J.-H. Kim, S.-H. Park, J.-G. Kang, and J.-T. Kim, "Experimental Performance of Heating System with Building-integrated PVT (BIPVT) Collector," Energy Procedia, vol. 48, no. Supplement C, pp. 1374-1384, Jan. 2014. https://doi.org/10.1016/j.egypro.2014.02.155.

[11] X. Cao, Y. Yuan, B. Xiang, L. Sun, and Z. Xingxing, "Numerical investigation on optimal number of longitudinal fins in horizontal annular phase change unit at different wall temperatures," Energy Build., vol. 158, pp. 384-392, Jan. 2018. https://doi.org/10.1016/j.enbuild.2017.10.029.

[12] Y. Yuan et al., "Coupled cooling method and application of latent heat thermal energy storage combined with pre-cooling of envelope: Method and model development," Energy, vol. 119, pp. 817-833, Jan. 2017.

[13] X. Yang, L. Sun, Y. Yuan, X. Zhao, and X. Cao, "Experimental investigation on performance comparison of PV/T-PCM system and PV/T system," Renew. Energy, vol. 119, pp. 152-159, Apr. 2018. https://doi.org/10.1016/j.renene.2017.11.094. 